\title{
Toward an Intercultural Understanding between the Orient and the Occident: A Narrative Approach to Translating Jihäd Concept into English
}

\author{
Alsayed Ismail \\ Assistant Professor, Prince Sattam \\ Bin Abdul-Aziz University, KSA
}

\begin{abstract}
Translating religious terms and expressions, particularly polysemous concepts like $J i h \bar{a} d$, is an intriguing area of research, since non-Muslim perceptions of Islam and Muslims are largely contingent upon their understanding of these translations. A translator's presuppositions exercise considerable influence on his/her rendition of religious concepts. At heart, the greatest issue in translating the religious text hinges on whether it may be considered conceptually untranslatable. An important issue regarding the translation of $j i h \bar{a} d$, is that religious expressions and terms are components of ancient and
\end{abstract}

classical texts 'travelling' from the past to the present; this alone brings about a number of significant problems in their understanding, interpretation, and translation. It has not yet been established whether religious terms like jihād preserve their meanings unchanged across time and space, or whether they are transformative and changeable. Therefore, the proposed study aims to address the issue of translating jihād concept into English through applying Baker's narrative approach.

Keywords: Jihād, Narrative theory, Islamic Tradition, Intercultural Understanding, 


\section{Toward an Intercultural Understanding between the Orient and the Occident: A Narrative Approach to Translating Jihād Concept into English}

Alsayed Ismail

\section{Introduction}

The greatest issue in translating religious terms like jihād hinges on whether it may be considered conceptually untranslatable. Proponents of this stance include von Humboldt, Virginia Woolf, Willard Quine, and Jacques Derrida. The concept of jihād can be subjected to a number of translation approaches including: corresponding equivalence; dynamic equivalence; cultural translation; domestication and foreignization; polysystem theory; and narrative theory. Benjamin (1969) argues that a "sacred text is untranslatable $[. .$.$] because the meaning$ and the letter cannot be dissociated" (84). An approach based on finding out a corresponding equivalence seeks an identical, definite, and explicit meaning in the target text; however, this may be an unachievable task with religious terms, which often have more than one meaning embedded in a single term. In the same vein, dynamic equivalence is based on the idea that the translation of religious texts and concepts has to be adapted to the culture of the receptor, who is unable to fill in the cultural and theological gap between source and target texts. The cultural approach may be unfit for rendering religious terms since it is unable to cross over the cultural differences between the source and target texts.

\section{Statement of the Problems}

Translating religious terms and expressions, particularly polysemous concepts like $J i h \bar{a} d$, is an intriguing area of research. Narrativity has a double impact on the translation of Jihäd. First, it may misrepresent the concept to a receptor who has his/her own set of presuppositions and biases. Second, a translator may not consider the importance of narratives in his/her translation, focusing only on rendering a narrow linguistic equivalence of the term.

Given that jihād has multiple meanings, how can a translator transfer this multiplicity of meaning clearly and comprehensibly into a foreign lexicon? The multiple meanings inherent in the concept of jihād can bring about different interpretations, sometimes even contradictory meanings, particularly when it is examined by scholars from different cultural and religious backgrounds. An important issue regarding the translation of jihād is that religious expressions and terms are elements of ancient and classical texts 'travelling' from the past to the present; this alone results in a number of significant problems in their understanding, interpretation, and translation. It has not yet been established whether religious terms like jihād preserve their meanings unchanged across time and space, or whether they are transformative and changeable.

\section{Research Questions}

This study attempts to answer three main questions.

First, how is the concept of jihād perceived in the source Islamic culture?

Second, how do the oriental translators render the translation of jihād into English? 
Third, how do the occidental translators render the translation of jihād into English?

\section{Methodology}

Quantitative and qualitative analyses are combined to study the intercultural understanding of jihād concept in the original Arabic holy text and in its English translations. With regard to the quantitative analysis, a corpus-driven extract of the concordance of the word $j i h \bar{a} d$ is retrieved. After the pre-processing of the corpus (normalization, cleaning and stemming) to be ready for use, it is composed of 106,789 tokens. The quantitative analysis generated 37 concordance lines (Appendix 1). Selective examples are then contrasted to the available English translations for measuring the intercultural understanding of jihād concept among the oriental and the occidental translators. A qualitative intercultural narrative approach is then used to address the (mis)conceptualization of $j i h \bar{a} d$.

\section{Review of the Literature}

Sharifian (2007) shows how culturally constructed concepts, such as jihād and 'compromise' are subject to significant influence from the socio-political contexts in which they are used. The author conclude that mistakes in translating such socio-culturally loaded conceptualizations could have unintended consequences that, in turn, could bring about damage to human life and spirit. Taibi, and Martin (2012) reiterate the same conclusion. They argue that constructing a narrative may serve its interests - either through indoctrinated translators or blatant manipulation.

Focusing on the narrative elements of setting, characterization and emplotment, Pfeifer and Spencer (2018) illustrate a possible ushering of jihād, as a concept which contains classical elements of a romantic story in which the everyday person is forced to become a hero in a legitimate struggle against an unjust order, towards radicalizing youth as well as justifying fighting and violence. Selective translations of jihād are viewed within Baker's narrative framework.

\section{Theoretical Background}

Through the use of Baker's narrative theory, narratives of the occidental conceptualization of jihād, which includes biblical narratives, traditional orientalists' narratives and modern orientalists' narratives, are viewed. All are then contrasted to the modern Islamic narrative on jihād as well as to that of the major fiqh schools.

\section{Baker's Narrative Theory}

Berge (2017) argues that accomplishing an accurate understanding of an Islamic religious text is a complicated and intricate issue because of the historical gap between the time of revelation and the time of compiling the revelation as a text. $\mathrm{He}$ writes: "Yet, an examination of these accounts and theories shows that the situation in early Islam was more complex, and more skeptical theories suggest those accounts are not just inaccurate, but were fabricated" (37). Therefore, translating jihād not only requires one to reconstruct the original historical context of a text, but also to invent methods to verify whether a reconstructed account is true or false. Narrative theory is proposed as an approach to disclose whether the translation of religious concepts like jiha $\bar{a}$ is precise and accurate: it not only involves the reconstruction of ancient accounts and their narratives, but also traces the development of these narratives and their influence on contemporary understanding of ancient and religious verses. 
I suggest Baker's narrative approach is an appropriate method for analyzing the interpretations and the translations of jiha $\bar{a}$ concept into English. Baker's narrative theory (2006) is an approach that uses narratives to analyze and verify the accounts and the translations addressing the concept of jihād to reach more accurate translation: "Narrative theory $[\ldots]$ allows us to piece together and analyze a narrative that is not fully traceable to any specific stretch of text but has to be constructed from a range of sources, including non-verbal material" (Baker, 2006: 3). Narrativity relies heavily on piecing together texts from various fragmentary sources and evaluating them as part of a larger integrated textual and contextual unit.

The core idea of such a narrative rests on its function, which may help reveal the ambiguity that conceals meaning and confuses the reader, but also on "shaping people's views of rationality, of objectivity, of morality, and of their conceptions of themselves and others" (Bennett \& Edelman, 1985: 159). Therefore, the translation of jihād should be analyzed, examined and interpreted by drawing together a number of disparate threads that trace its development through narratives across time and space, in order to generate its true meaning. This process includes both past and present narratives. Given the principle that past narratives determines the present, Baker argues that the translator should not just translate a concept precisely, but also examine the narratives in which the concept is embedded.

Applying Baker's narrativity approach requires a number of steps: i) critically examine jihād narrative in the Western culture; ii) critically study the narrative addressing the interpretation of $j i h \bar{a} d$ in the sayings of the Prophet iii) critically inspect the concept of jihād in the four major Figh schools; iv) study the narratives presented in the work of prominent Islamic scholars from both the past and present; v) reconsider the translation of certain verses on jihād in light of these narratives and Baker's narrative theory.

\section{Narratives of the English Mind on Jihād}

Indeed, it is difficult to cover the whole heterogonous and varied western narratives addressing jihād concept in such a brief study. The narratives of the English mind under examination are primarily derived from the biblical studies, the narratives on Crusade and just war theory, the Orientalists' narratives and so on. These selected types of narratives shape the mainstream western narratives on Jihād. Orientalists have made a remarkable contribution to the study of $J i h \bar{a} d$; they have examined it from both theological and cultural perspectives (Gibb, 1945; Renan, 2015; Nöldeke, 2013; Crone \& Hinds, 2003; De Long-Bas, 2007; Peters, 1979). The study of jihād has found new relevance in the work of some Western contemporary writers (Lewis, 1995; Spencer, 2007; Pipes, 2002; Patai, 2014). However, these studies have not addressed the problems of translating jiha $\bar{a}$ and the impact of intercultural misunderstanding as a result of flawed rendition of this concept-their studies have focused on presenting the various contemporary interpretations.

\section{The Biblical Narratives}

Jesus's sermons on the Mount provide a platform for mapping out the Westerners' narratives on the concept of Jihäd. Jesus said: "But I tell you, do not resist an evil person. If anyone slaps you on the right cheek, turn to them the other cheek also. ... love your enemies and pray for those who persecute you (Matthew 5:3, New International Version)." It is crystal clear 
that the teachings of Christianity are absolutely pacifist, and order its followers to love all humanity regardless of their faith or culture. They represent a fertile soil for disseminating the seeds of the interreligious dialogue. Therefore, Christianity does not promote violence or fighting for spreading the word of God. It teaches its people to love their enemies and pray for them. This contributes largely to constituting the Westerners' presuppositions on the concept of Jihäd.

In Christianity, the concept of fighting for spreading the word of God is almost non-existent. However, it has been claimed by many scholars that the Crusades adopt the concept of Holy war in order to justify its war against Muslims. It seems that the term jihād has its resonances for Westerners in the ways in which it epitomizes the concept of Holy war. Therefore, Westerners' presuppositions of jihād may be derived from their understanding of the Crusades. Lewis (1995) elaborates further on this issue in the following:

Even the Christian crusade, often compared with the Muslim Jihād, was itself delayed and limited response to the jihād and in part also an imitation. But unlike the Jihād, it was concerned primarily with the defense or re-conquest of threatened or lost Christian territory....The Muslim jihād, in contrast, was perceived as unlimited, as a religious obligation that would continue until all the world had either adopted the Muslim faith or submitted to the Muslim rule...The object of jihād is to bring the whole world under Islamic law (233-234).

Lewis explains that crusade was a response to jihād and aimed to stop the Islamic expansion in the Christian world and recover the Christian lands conquered and occupied by Muslims. It did not aim to convert Muslims to Christianity, nor even to spread Christian faith. It was a defensive war rather than an expansive war However, jihäd is unlimited and continued Islamic obligation, the objective of which is to convert Christians and their countries to Islam or pay the Jizya with willing submission, and feel themselves subdued.

The Westerners' set of presuppositions and preconceptions of the concept of war and peace, which are primarily derived from the scripture, the concept of holy war and the just war theory, represents the starting point for elaborate accounts concerning jihād concept. Therefore, translators who culturally and religiously belong to the West would inevitably encounter a serious problem of translation when rendering the concept of jihād into English due to the lack of cultural and religious concepts in the target language.

\section{The Traditional Orientalists' Narratives on Jihād}

Gibb (1949) explains that Islam expansion was realized through a skillful government and through strong armies. $\mathrm{He}$ writes: "these astonishing victories, the precursors of still wider conquests ... confirmed the character of Islam as a strong, self-confident, conquering faith"(3). According to Gibb, Islam was characterized by conquering faith, and it was fueled by the religious teachings of fighting for the cause of Allah. However, this conquering faith laid the groundwork for incorporating the Islamic culture and religion into the conquered lands. Though Gibb claims that Islam spread by conquering the world, he admitted that it managed to assimilate the conquered land and its people into the Islamic culture. It seems that Gibb's understanding of the concept of $j i h \bar{a} d$ in Islam was influenced by the just war theory which is largely a Christian philosophy that lays a moral groundwork for war, as he conceded that 
"Islam emerged into the civilized outer world....as a moral force that commanded respect" (3).

\section{Modern Orientalist's Narrative on Jihād}

Heck (2004) writes:

If Jihâd-struggle in the path of God (jihäd fi sabil allah) - is taken to be struggle for Islamic hegemony(privileging Islam over other religions and the interests of Muslims over non-Muslims within the socio-political order), it will be impossible for non-Muslims to embrace it, and the use of force to establish such hegemony will result in the identification of Islam with violence. (This is not to take from Muslims the right to build up and nurture their religious community and to consider such a work a struggle for God's cause, but rather to recognize that jihâd-a concept specific to a particular religious community-is meant to serve a public purpose.) If, alternatively, jihād is taken to be a struggle to form and defend a moral society, it will be possible for the non-Muslim to participate alongside the Muslim in jiha $\bar{d}$, if the goal is clearly defined as the good, even to the extent of using force to achieve such a goal. (96)

It is clear that Heck's understanding and interpretation of jihād is largely influenced by his own set of presuppositions that resulted from the biblical narratives and the just war theory. This would be reflected in his argument entailing that the accurate understanding of $j i h \bar{a} d$ rests upon perceiving whether its goal is ethical or unethical. However, the Quranic use of jihād term may conceal more than it reveals, as the receiver, whose cultural and religious backgrounds do not belong to Islam, may be unable to distinguish between the ethical and unethical meanings embedded in such a polysemous term. Rather, he unconsciously perceives it in terms of his cultural presuppositions and preconceptions. Knapp (2003) explains "that the word "jihād" means "struggle" or "striving" (in the way of God) or to work for a noble cause with determination.

Cook (2005) argues that the concept of jihād refers to a physical warfare. $\mathrm{He}$ expounds that the idea of spiritual struggle or struggle against evil desires can be seen as a lesser form of jihād. He further argues that Quran adopts an aggressive doctrine of jihād (2005: 2-3). He holds that the Western scholars invested too much in the concept of the spiritual jihād which was primarily reintroduced by Al-Ghazali who died in the beginning of the twelfth century (37). This casts doubts upon the authenticity of the hadith propagating a pacifist concept of Jihäd, namely the spiritual struggle, since "there is usually a significant gap of decades, even centuries, between the time the words were first spoken, recited, sung, composed, and/or written and the time they became encapsulated within a text"(Berg, 2017: 37)

Crone (2012) explains that jihäd is a kind of war, which is not secular but religious. However, she distinguishes between what Quran has to say about jihäd and the rules derived by the Muslim jurists on the concept of Jihād. She writes: "What the Quran has to say on the subject is a different question: the rules it presupposes seem to be a good deal more pacifist than those developed by the jurists and exegetes."

It seems that the Western narratives on jihād are largely influenced by the biblical teachings, the concept of the holy war and the just war theory in Christianity. These 
major points represent the starting point in perceiving the concept of jihād. They were largely influenced by their presuppositions in understanding such a concept and they often tend to regard it as a pacifist concept. Among non-Muslims, the concept of jihād often refers to holy war, to strive, just war, or at least a physical warfare.

\section{Islamic Narrative on Jihād}

Examining the Islamic narratives on $j i h \bar{a} d$ is essential since it offers the Islamic historical experience of jihād that contributes largely to constituting Muslims' presuppositions and assumptions on the concept itself. However, I focus on examining the Sunni narratives simply because $90 \%$ of the World Muslim population belongs to Sunni Islam, whose understanding and interpretations of Islam are mainly derived from Quran, Hadith and four major Figh schools. In addition, Sunni Muslim scholars, both traditional and contemporary, have categorically rejected all methods of interpreting the Quran outside the confines of its text and that of the prophetic Hadiths and the major Fiqh schools

In Lesān $\bar{a} l$-' $r a b$ Dictionary, the term jihād is derived from Al-jūhd, exerting energy and power, and jīhāad, undergoing hardship and painful experience. AlMātrizī (1979) explains that jihād is mainly concerned with the idea of fighting an enemy. When one encounters an enemy, one has to endure the consequences of fighting it. In the Islamic Sharia (legal) tradition, however, it generally refers to fighting disbelievers (171, my translation). Al-Dūksī (1988) argues that the concept of Jihäd, as referred to in the Quran, is a holistic term that can be defined as 'doing one's best for the sake of Allah,' whether this is done through spending one's own wealth or sacrificing one's life. Jihād can be considered the individual duty of Muslims when they are attacked by an enemy or face aggression, and a collective duty when Muslims feel secure (172, my translation). In other words, jihād is mainly related to the concept of fighting and it is always put in force whether Muslim's lands are attacked or not. Therefore, it is used as a kind of discourse that aims to impose a global Islamic worldview upon other nations. The Islamic Sharia divides the concept of jihād into general and specific forms; these, however, overlap and intertwine to varying degrees.

Examples of Modern Islamic Narrative on Jihād

Al-Banna (2002) argues that Muslims have been humiliated and colonized by infidels, their lands occupied, their privacy violated, their enemies have control over their affairs, and their religious rites have been suspended in their own homes. In addition, they have been stopped from spreading Islam. Therefore, jihād has become an absolutely individual obligation and everyone must be prepared to engage in jihād at the first opportunity.

Qutb (1983) regards contemporary Muslim society to be jāhilī or ignorant, and Muslims to be following similar norms and values to the pre-Islamic period or jahilizyyāh. He also adds that the true enemies are jāhili governments and expressly calls for their eradication through Jihād. Here, jihād means fighting against jāhilī regimes in Muslim countries, which are still following a pre-Islamic lifestyle, and replacing them with an Islamic system of government. This shifts the focus of the concept of jihäd from a purely religious one of fighting for Allah to a kind of secular resistance tinged with Islam.

Albouti (1993) tends to promote a pacifist concept of $J i h \bar{a} d$. He explains that 
the core idea of jihâd is to argue logically with polytheists; to distinguish truth from falsity; to reveal suspicion; and to assist Muslims in doing good works. That is to say, jihād on the personal level is not an end in itself, but a means to achieve more ambitious goals of individual betterment. He favors the concept of jihäd adopted in the Meccan Surahs that propagates pacifism. He states that the Meccan concept of jihād represents the mainstream narrative in Islam and it is the origin and the foundation of jihād in Islam. He supported his claim by restoring to the following hadith: 'What is the greater Jihād?' The Prophet (peace be upon him) said, 'It is someone's resistance against his evil desires. In this way, jihäd concept in Islam is mainly a pacifist concept, which is known as the resistance of one's own evil desires.

Alqaradwi (2014) argues that jihād refers to one's own inner-self struggle, struggle against Satan, promoting virtue and preventing vice, speaking truth to tyrants, and so on and it also includes the concept of fighting for the cause of Allah. (2014:Author's trans., 67). He further argues that the idea of fighting is not only confined to the infidels but also to those who rebel against carrying out the pillars of Islam like prayer, and zakat. According to him, jihād in Islamic sharia refers to fighting and it is made up of two major categories: defensive fighting and expansive fighting (My translation, 68). Defensive fighting refers to resisting the enemy if he invades the abode of Islam. The second type is the expansive jihâd as Muslims have to attack the enemy in his homeland for expanding the land of Islam and securing the Islamic borders, which has recently been known as the preemptive war.

In modern times, the concept of jihād has changed to signify a kind of revolution: "Jihād refers to that revolutionary struggle and utmost exertion which the Islamic Nation/Party brings into play to achieve this objective" (AlMawdudī, 1930: 2). Jihād is considered a kind of war waged for the prosperity and welfare of the entirety of humanity and solely in the cause of Allah.

The Concept of jihād in the Major Fiqhī Schools

Zada (1998) states in Mūgma al-anhur (Rivers' Collection) the rules of jih $\bar{a} d$ in the Hanafi school:

Jihād literally means 'exerting one's own best' including sayings and actions. In sharia, it means fighting unbelievers and their like which includes actions such as hitting them, plundering their resources, destroying their temples and breaking their idols. " (My translation, 632-633).

Al-Sawī (1995), a traditional jurist, writes about the Maliki School's understanding of Jihād:

Jihād for the cause of Allah is a collective duty, that is, if some Muslims are involved in it, the remaining shall be exempted. It can be enforced as an individual duty, like fasting and prayer, upon the request of the Imam or when Muslims are attacked in their homeland. (My translation, 198-208)

Al-Shirbīni (2000), a traditional Jurist, writes about the Shafi vision of jih $\bar{a} d$ as follows:

Jihād during the life of the Prophet was a collective obligation; others have said that it was an individual obligation. (My translation., 3-22).

Ibn Qudāma(1999) writes about the Hanbalī concept of $J i h \bar{a} d$ 
The issue of $j i h \bar{a} d$ is a collective duty when some people are involved in it; it is no longer an individual duty. Jihād must be an individual duty if one of the following three conditions is to be fulfilled: two fighting armies face one another; infidels invade a Muslim country; an Imam orders Muslims to fight. Jihäd must be conducted once annually in the worst cases. (My translation, 6-13)

Passing a critical eye over the narratives on the concept of jihād in the major fiqhī schools, one can see that they agree that the concept of jihād definitely refers to fighting for the cause of Allah. Therefore, it is necessary to shift the focus on the concept of jihād in the Sunnah.

\section{The Concept of jihäd in the Sunnah}

The Sunnah abounds with hadiths that explain the meaning of jihād. Among these sayings are the following:

Abu Hurairah (May Allah be pleased with him) reported:

The Messenger of Allah said, 'The gates of Jannah are under the shades of the swords.' A man with a shaggy appearance got up and said, 'O Abu Musa! Did you hear the Messenger of Allah say that in person?' Abu Musa replied in the affirmative; so he returned to his companions and said: 'I tender you farewell greetings." Then he broke the scabbard of his sword and threw it away. He rushed towards the enemy with his sword and fought with it till he was martyred" (Muslim: Book 12, Hadith 1302).

Al-Khātīb Al-Būghdādī narrated this Hadith with the following words, 'We have come back from the lesser jihād to the greater one. They said, 'What is the greater Jihād?' The Prophet (peace be upon him) said, 'It is someone's resistance against his evil desires.' (13/523-524)

The majority admit that jihād refers to fighting for the cause of Allah. A few hadiths state that Jihād, in its full manifestation, also implies resisting one's own desires. This contradiction can easily be revealed when verifying which narrative is rather authentic. Ibn $B a z$, a well-known, modern Saudi jurist, explains that the hadith that states "we have come back from the lesser jihād to the greater one" is inauthentic. In his Fatwa, Ibn Baz writes:

'We have come back from the lesser jihād to the greater one,' it is groundless and none of those who are known for being acquainted with the words and actions of the Prophet related it" (Book on Hadith Mawdu', Part No. 26, p.381).

Examining the narrative articulated around jihād pays dividends: those who claim that the concept of jihäd refers to the struggle of the inner-self and against the devil have constructed their judgment from an inauthentic prophetic saying that contradicts the mainstream narrative of jihād identified with fighting. Indeed, these sayings that have identified jihâd as the resistance of desire and struggle against the devil and with the inner-self are inauthentic and baseless according to the authentication of the Prophet's sayings. Critically tracing the narrative in which jihād is embedded, one reaches the unmistakable judgment that it generally referred to fighting for Allah's cause in the past and refers to a kind of Islamic revolutionary act or Islamic resistance to jāhilī societies in the present (seen to be Muslim in name only, but considered secular and un-Islamic in practice). This represents a starting point for fighting against all non-Muslims to spread the word of God. 
Analysis: $\quad$ Intercultural/Interreligious Understanding Between the Orient and the Occident.

In English, jihād, has two senses. Jihād is defined as a holy war waged by Muslims against infidels (fighting). Jihäd is also defined as a holy striving by a Muslim for a moral or spiritual or political goal. The focus of analysis of the following translations is on how jihād concept is translated. The translation analysis is divided into two categories, the first category renders it as "striving" and the second category renders it as "fighting." The translators are religiously and culturally grouped. The first group is made up of those translators who belong to the Western culture and believe in Christianity or those who have Christian background. This categorization is made intentionally in order to stress how cultural and religious impact is necessary for shaping translators' understanding and perception of jihād concept. In other words, the grouping can explain clearly the major role of the translator's religious and cultural presuppositions in constituting his views and consciousness of the external realities, as his translation would inevitably be governed by his preconceived ideas, his cultural and religious values. These external influences cannot be either consciously or unconsciously suppressed or neutralized when translating, and may result in producing a prejudiced translation. Therefore, the intercultural and interreligious understanding may help in deconstructing the translator's set of presuppositions and his prejudice. Indeed, the translator is embedded in his narrative that builds up his presuppositions, assumptions and prejudiced thinking and constitutes his translation choices.

The original transliterated verse reads:
Laa yastawil qaa'idoona Minal mu'mineena ghairu ulid darari walmujaahidoona fi sabeelil laahi bi amwaalihim wa anfusihim; faddalal laahul mujaahideena bi am waalihim wa anfusihim 'alalqaa'ideena darajat; wa kullanw wa'adal laahul husnaa; wa faddalal laahul mujaahideena 'alal qaa'ideena ajran 'azeemaa. (an-Nisa-95)\

Example \#1: Occidental Translators of Originally Christian Background:

\section{Translation of Jihād as 'Striving'}

1. George Sale (1697- 1736) is a Christian orientalist who was well-versed in the Islamic culture. His translation of Quran has been reprinted in modern times. His translation was praised by many orientalists.

Sale (1734) translates jihād as "who employ their fortunes and their persons for the religion of God."

2. John Medows Rodwell (1808-1900) was an English clergyman of the Church of England. The Koran was first published in 1861. According to Jones (1994), his translation has much better cross-referencing to biblical texts, which is "crucial to one's understanding if the Qur'an".

Rodwell (1861) translates jihād as "those who do valiantly in the cause of God with their substance and their persons."

3. Edward Henry Palmer (1840-1882) was an English orientalist and explorer. He produced his translation of Quran in 1880 .

Palmer (1880) translates jihād as "who are strenuous in God's way with their wealth and their persons."

4. Muhammad Marmaduke Pickthall (1875 -1936) was a Western Islamic scholar noted for his English 
translation of the Qur'an (1930). He was a convert from Christianity.

Pickthall (1930) translates jihād as "who strive in the way of Allah with their wealth and lives"

Oriental Translators of Islamic and Middle Eastern Background

\section{Translation of Jihäd as 'Fighting'}

1. Yusuf Abdullah Ali (1872- 1953) is a British-Indian Muslim scholar. He was born in India where he spent his formative years. Later, he converted from being a Shiite Muslim to be a Sunni Muslim. His translation of the Qur'an into English is one of the most widely known and used in the Englishspeaking world.

Ali (1934) translates jihād as "who strive and fight in the cause of God."

2. Nessim Joseph Dawood (1927 -2014) was born in Baghdad to a Jewish family. He came to England as an Iraqi state scholar in 1945, and studied English Literature and Classical Arabic at the University of London. His translation of the Quran is considered one of the best-selling English language versions - it has been reprinted at least 70 times.

Dawood (1956) renders jihād as "those who fight for the cause of God with their goods and their persons."

3. Ahmed Ali (1910-1994) is a Pakistani novelist, poet, critic, translator, diplomat and scholar. Al-Quran, A Contemporary Translation (Princeton University Press, Oxford University Press \& Akrash) is the most outstanding contribution in the field of translation. Approved by eminent Islamic scholars, it has come to be recognized as the best existing translations of the holy Quran.
His translation: Ali (1984) those who fight in the way of God with their wealth and lives.

4. Sayyid Ali Quli Qarai is an Indian-born Shia scholar and his translation was produced by the Iranian Centre for Translation of the Holy Qur'an.

Qarai (2005) translates jihād as "those who wage jihâd in the way of Allah with their possession and their persons."

5. Ali Ünal was born in 1955 in Uşak, province of Turkey. He is a Turkish author. He is often associated with the Gülen Movement, an Islamic group in Turkey. Ali Ünal's translation uses contemporary English, which makes it more readable than some classical Quran translations.

Ünal (2006) renders jihād as as "who strive and fight in the cause of God."

6. Muhammad Muhsin Khan was born 1927 in Pakistan. He belongs to Pashtun origin, most notable for his English translations of Sahih alBukhari and the Qur'an, entitled The Noble Qur'an.

Khan (2008) translates jihäd as "those who strive hard and fight in the cause of Allah with their wealth and their live."

Example \#2: $\quad$ Oriental Translators of Islamic and Middle Eastern Background

The original transliterated verse: Infir $\bar{u}$ Khifäfāan Wa Thiqālāan Wa Jāhidū Bi'amwālikum Wa 'Anfusikum F̄̄ Sabīli Allāhi Dhālikum Khayrun Lakum 'In Kuntum Ta lamūna (42, al-Tauba).

Dr. Muhammad Mahmoud Ghali was born in 1920 in Egypt. He was a professor of Linguistics and Islamic Studies at AlAzhar University (Cairo, Egypt.) Dr. Ghali 
has spent 20 years interpreting the meanings of the Quran into English.

Dr. Ghali (1997) translates jihād as: "March out, light and heavy! And strive with your riches and yourselves in the way of Allah. That is most charitable for you, in case you know (42, al-Tauba)."

The translator oversimplifies the meaning of Khifäfāan wa Thiqālāan as "light and heavy." The phrase "light and heavy" offers open-ended meanings. For example, it can be interpreted as 'healthy and sick' and 'rich or poor' and represents an irrevocable divine order that jihād is an individual duty that has to be imposed on every Muslim regardless of his sex, age, healthy conditions, social status. However, this interpretation contradicts the principle that jihäd is a collective duty, which, if it is performed by some people, those remaining are exempted from it. It turns jihād into an absolutely individual duty that must be imposed on every Muslim.

Moreover, this translation contradicts a following verse which was claimed to have abrogated it: "There is no blame on those who are infirm, or ill, or who find no resources to spend (on the cause), if they are sincere (in duty) to Allah and His Messenger: no ground (of complaint) can there be against such as do right: and Allah is Oft-forgiving, Most Merciful" (AtTawba: 91).

In addition, this verse was revealed to the prophet during the conquest of Tabuk: some men and women did not join the Muslim army in this invasion and were not criticized by the Prophet. Therefore, if it is translated as "light and heavy," the meaning of the verse contradicts the Sunnah and other verses of the Quran itself. Therefore, translating it as "light and heavy" requires the translator to render $\mathrm{Wa}$ Jāhidū as "to fight" rather than "to strive." Indeed, with such an abrogated verse that contradicting the mainstream narrative of the hadith, revealing the suppressed narrative is a priority for a translator to offer an accurate and precise translation. According to the principle entailing that jihād is a collective duty, if this verse is abrogated by translating it as "light and heavy" it is a misleading translation that suppresses the narrative of the Sunnah and other Qurnaic verses. The translator accentuates that the concept of jihād may have other senses different from "to fight" and these senses can be deduced by the reader. Here, a particular translation is accentuated representing a particular ideology at the expense of providing an accurate and clear translation.

\section{Discussion}

The translations under examination and analysis are selected in relation to the following criteria: First, the set of presuppositions of each individual translators, his/her cultural and religious backgrounds and their effect on the translated concept are to be taken into consideration. Second, this cultural and religious effect can be easily accomplished by subjecting the translated text to a selective appropriation of textual material, which traces "the patterns of omission and addition designed to suppress, accentuate or elaborate particular aspects of a narrative encoded in the source text or utterance, or aspects of the larger narrative(s) in which it is embedded" (Baker,2006:114). Third, the historical period in which a translation was produced. Fourth, the credibility and the trustworthiness of the translator who produced the translation. Third, the credibility of the translation and its approval by eminent scholars. Finally, the translations should be widely readable.

As for the translation of Jihād concept as striving, translations were chronologically traced as these translations 
were produced during the $18^{\text {th }}$ and the $19^{\text {th }}$ century and the first half of the $20^{\text {th }}$ century. They were translated by Christian English orientalists and a Western Islamic scholar of a Christian background, whose set of presuppositions and assumptions are mainly derived from their cultural and religious narratives.

The translators have switched between translating Jihād as "to strive to," "to do valiantly," or "employ their fortunes and their persons for the religion of God." They have suppressed the verb "to fight" and have replaced it with "strive with their lives for the cause of Allah." These translations were largely affected by the mainstream narratives in their own culture derived from their biblical studies which do not have the corresponding equivalence of such a term. Their set of presuppositions of the concept vary from the original concept in the source language, which makes their translations contradict the authentic narratives of the hadith and the opinions of trustworthy jurists who have stated that the concept of jihād refers to fighting in the cause of Allah. What is accentuated is a narrative confirming that the concept of jihād has little to do with the concept of fighting. Most of the older translations of the Quran, with a few exceptions, tended to translate the concept of jihād as "to strive in Allah's cause."

Historically, an extended period of time did not witness the Islamic revival, the proliferation of terrorist attacks and the widely spread discourse of fanatical Islamism. In this period, the Islamic discourse tended to be pacifist, which partly explains why the idea of translating $j i h \bar{a} d$ as fighting was generally avoided in the early translations of the Quran; the orientalists who made these translations have always been accused by scholars as biased and prejudiced against Islam. For example, Sale translates it as "and those who employ their fortunes and their persons for the religion of God."

This translation represents a very pacifist meaning of Jihād. Its aggressive tone has been accentuated slightly in the translation of Rodwell, who translated it as "who do valiantly in the cause of God with their substance and their persons." The connotation of fighting valiantly is kept to a minimum. The fighting tone was reflected in the translation of Palmer to a greater degree, who rendered it as "who are strenuous in God's way with their wealth and their persons." At the beginning of the twentieth century, jihād started to be translated as a 'to struggle and strive,' the relatively more warlike connotation of which is noticeable.

With regard to the translations of jihād as fighting, it seems that this conceptualization became a predominant trend since the start of the twenty-first century when the shifting realities of terrorism and fanaticism have the consciousness of the translator's concept of fighting and reconsidered it in terms of contemporary and traditional narratives since then it has become the norm with many translators to render it as 'fighting'. The translators do not suppress the direct meaning of jihād as equivalent to fighting. It is crystal-clear that those translations of jihād as fighting in Allah's cause have been largely influenced by the Islamic revival that has emerged since 1970 . This fueled the theory of Islamic expansion, the negative consequence of which was the sparking of the terrorist attacks across the world culminating in the destruction of the World Trade Center in 2001 and the emergence of ISIS. These issues have unconsciously affected those who are engaged in translating the Quran, particularly with the concept of Jihād. In 
this way, translation is congruent with circumstantial reality.

It is also obvious that the backgrounds, presuppositions and assumptions of the translators have largely influenced their understanding and their translations of jihäd concept. Most of the translators who render jihād as "fighting for Allah's cause," grow up in Islamic countries in the Middle East, India and Pakistan where Sunni interpretations of the religious text prevailed, which unconsciously affects the mind of the translators. The translators render jihād as "fighting for Allah's cause," which is also largely consistent with the authentic narratives of the hadith and the opinions of trustworthy jurists and contrary to the pacifist concept of Jihäd. Indeed, the translator is embedded into the narrative of his source text and this unconsciously guides his translation.

$J i h \bar{a} d$ in example \#2 is best rendered as "to fight" for the following reasons. The traditional Sunni narrative on the concept is a 'coherence narrative' reflecting that jihād refers to "fighting for the cause of Allah" as there is an "internal consistency of the narrative - whether or not it reveals contradictions within itself in form or reasoning" (Fisher, 1997: 315). Jihād is regarded as an inner struggle with the self in Sufism. The Sunni narrative goes against this by stating that which was not originally articulated by the Prophet is classified as inauthentic. In addition, a great deal of Sunni material representing the concept of $J i h \bar{a} d$, from both the present and the past, shows material coherence as a narrative on jihād and it "relates to other narratives that have a bearing on the same issue with which we are familiar" (Baker, 2006: 168).

The opinions and narratives of jihād used in this study reflect a characterological coherence that "assumes that the reliability of any narrative depends, to a significant extent, on the credibility of its main characters, whether narrators or actors within the narrative" (Baker, 2006; 165). The narrative introduced in this study, drawn from hadith and the opinions of jurists, is based on credible sources and trusted narrators. Elements reflective of contradiction or proving inconsistent are excluded after being highlighted and discussed. The second step after making sure that the narrative used shows a clear material coherence is to verify that this narrative shows fidelity: "Fidelity ... is assessed by applying the logic of good reason, which requires a narrative to be examined with reference to "the soundness of its reasoning and the value of its values" (Fisher, 1987:88).

The narrative used in this study has been logically assessed: elements that are expected to show logical fallacies or contradictions are excluded after being clearly highlighted. In this sense, a number of translations of jihād and the various types of narratives on jihād are logically assessed and views and opinions considered logically inconsistent are excluded. The understanding, interpreting, and translation of the concept of jihād rely heavily on the contextual elements surrounding the text and conformity with contemporary realities. If the translated verse does not fit well with contemporary realities and modern readership, it is characterized as an unfaithful translation. This would be reflected in those translations that tend to promote a more pacifist concept, which goes against contemporary realities.

In addition, the value of the narrative to the world and humanity is another important element of narrative fidelity: "a value is valuable not because it is tied to a reason or is expressed by a reasonable person per se, but because it makes a 
pragmatic difference in one's life and in one's community" (Fisher 1987: 111; emphasis in the original). Therefore, examining the narratives on jiha a d can be considered to offer an important insight in providing an accurate and precise translation and encouraging intercultural and interreligious understanding between Muslims and non-Muslims

\section{Conclusion}

The Islamic mainstream narratives on jihād promote the concept of fighting for the cause of Allah, which is clearly reflected in the authentic hadith, the opinions of the notable jurists, and the four Fiqh schools. Additionally, the translations of jihād concept examined in the study, which were produced by oriental translators, render it as a fighting for the cause of Allah. This explains the impact of the narratives on the mind of the translators. The Occidental mainstream narrative examined in the study was heterogeneous and it almost depicts jihād as a pacifist concept, the meanings of which range from "striving, holy war to just war". The translations examined in this study, which were produced by Western Christian translators or Western Muslim translators, render it as to strive or 'struggle'. The significance of narrative theory for the translation of jihād rests upon filling in the interreligious gaps that accompany the development of the concept. The narrative theory in translating jihād concept gives translators an access to comprehend the concept of jihād clearly and reconsider its repercussions on the Muslims' minds. 


\section{References}

Al-Asfāhanī, R.2010) Al-Mufrādat fì -ġā̄rb al-Kor'n: A Dictionary of Qura'nic Terms. $1^{\text {st }}$ ed. Safwan Adnan Al-Dāwūdī, Bruit: Dar Al-Kālam.

Al-Bana, H. (2002) Mājmūat Rasa'l Hassan Al-Banna. First Edition. Alexandria, Dar Al-da'wa,

Al-Bouti, Ramdan. (1993). Jihad fi Sabil Allah: Theory and Practice. Beirut: Dar Alfkr.

Al-Bukhari, M. Sahih Al-Bukhari: Book of Jihād. ed. Muhammad Nasser, Beirut: Dār Ibn Kathīr.

Al-Dūski, S. (2008). Hašayat Al-Dūski ala-l-šarh al-kabīr, vol.2, ed. Muhammad U'lī̌s, Beirut: Dar Al-fikr Publishing House.

Ali, A. (2007) Al-Qur'an: A Contemporary Translation, USA: Princeton University Press,

Ali, A. Y. (2006). The Meaning Of The Holy Quran, U. S.A: Amana Pubns, $11^{\text {th }}$ edition.

Al-Mātrizīi, N. (1979). Al-mūğarb fe tarīb al-mu'rab, vol.1, eds, Fakhurī Mahmūd and Mukhtār Abdul Hamīd, Aleppo: Maktabat Usama Ibn Zaid.

Al-Maududi, A. A. (1930) Al-Jihād fì Sabīl Allāh, ktab. INC: India.

Al-Qardawi, Youssef. (2014) Fiqh Al-Jihad: A Comparative Study of the Rules and Philosophies of Jihad in the Light of Koran and Sunnah. Cairo: Wahba Publishing House.

Al-Sawī, A. (1995) Bulgat Al-sālīk le-a'krab Al-masālīk, ed. Muhammad Shāhīn, Egypt: Dar Al-Ma'rif.

Al-Shirbīni, A. (2000) Al-Sirāğ Al-Mūnīr Fì-l-Ǎna Ala Ma'rfat Ba'd Ma'ani Kalām Rabna Al-hākìm Al-habì̄r, eds, Ali Mūawd, \& Adil Abdulmawgūd, Beirut, Lebanon: Dar Al-kūtb Al-A'lmyia.

Al-Turmdhī, A. (1996) Sūnan Al-turmdhī. ed. Bashār Awad. Beruit: Dar Algharb Al-Islami

Baker, M. (2006) Translation and Conflict: A Narrative Account, London: Routledge.

Baker, M. “'Reframing Conflict In Translation'. Social Semiotics, 17 (2007),151-169.

Benjamin, W. (1969) “The Task of the Translator", in Illumination, Trans by Harry Zhon, New York, Schocken Books.

Berge, H. (. 2017) The collection and canonization of the Qur'Ān, London, Routledge.

Cook, D. (2005) Understanding Jihad, University of California Press, California.

Crone, P. \& Hinds, M. (2012) God's Caliph: Religious Authority in the First Centuries of Islam. UK: Cambridge Oriental Publications.

Dawood, N J (2014). The Koran. London: Penguin Books

Derrida, J. (1985) The ear of the Other: Otobiography, Transference, Translation: Texts and Discussions with. Christie V. McDonald (Trans.) New York: Schocken Books. 
Douglas E, S. and Harry D, T.1., IV." Choosing Words carefully: Language to Help Fight Terrorism," IOSphere (Fall,2006)4-6

Edelman, M. (1985). Toward a New Political Narrative. Journal of Communication, 35, 158.

Even-Zohar, R. "Polysystems Studies”, Poetics Today, 11(1995), p.3-15.

Fisher (1987) Human Communication as Narration: Toward a Philosophy of Reason, Value, and Action, Columbia: University of South Carolina Press.

Fisher, W. R. (1987) Narration, Reason, and Community, in Memory, Identity, Community: The Idea of Narrative in the Human Sciences. eds, Lewis P. Hinchman and Sandra K. Hinchman Albany: State University of New York Press.

Ghali, M. (2003) Towards Understanding the Ever-Glorious Qur'an, Egypt, Dar An-Nashr for Universities.

Gibb, H. (1949) MOHAMMEDANISM: An Historical Survey, London, Oxford University Press.

Heck, P. L. (2004). Jihad revisited. Journal of Religious Ethics, 32(1), 95-128.

Hiddas, M. (2014). A Higher-Order Functional View of Translation. Arab World English Journal. Special Issue, p212-224.

Hijjo, N. F., \& Kaur, S. (2017). The Paratextual Analysis of English Translations of Arabic Media Narratives on Daesh. 3L: Language, Linguistics, Literature, 23(3)

Humboldt, W. (2002) Introduction to the Translation of Aeschylus's Agamemnon.\| (1816). Trans. Douglas Robinson. Western Translation Theory: From Herodotus to Nietzsche. Eds. Douglas Robinson. Northampton: St. Jerome Pub.

Ibn Hanbal, A. (2009) Musnad Ahmad. Ed. 'Arn'ut, Cairo: 'A-rissala.

Ibn Qudāma, A. (1999) Al-Mugni. Riyadh, Dar- A'lm Al-Kitab

Jackson, S. A. (2006) 'Jihad and the Modern World,' In Islam in Transition, eds, Donohue, John J. and Esposito, John L, New York: Oxford University Press.

Johnson, J. T. (2014) Just War Tradition and the Restraint of War: A Moral and Historical Inquiry, New York: Princeton University Press.

Khan, M.M. (2008) Translation of the Meanings of the Noble Qur 'an in the English Language, Madinah: King Fahd Complex for the printing of the Holy Qur'an.

Knapp, M. G. (2003). The concept and practice of Jihad in Islam. Parameters, 33 (1) 82-93.

Bennett, W. L., \& Edelman, M. (1985). Toward a new political narrative. Journal of communication, 35(4), 156-171.

Lewis (1995). The Middle East: A Brief History of the Last 2000 Years. New York: Scribner.

Lewis, B. (1995). Cultures in Conflict: Christians, Muslims, and Jews in the Age of Discovery by Bernard Lewis. UK: Oxford University Press. 
Luxenberg, C. (2007) The Syro-Aramaic Reading of the Koran. UK: Prometheus Books.

Medows, J. (1734). The Koran. USA: Bantam Classics.

Palmer, E. H. (1880). The Quran. Oxford: Clarendon Press.

Pati, R. (2014). The Arab Mind. USA, Recovery Resources Press.

Peters, R. (1979). Islam and Colonialism: The Doctrine of Jihad in Modern History, Netherlands: Mouton Publishers.

Pfeifer, H., \& Spencer, A. (2018). Once upon a time: Western genres and narrative constructions of a romantic jihad. Journal of Language and Politics. Article in press. DOI: $10.1075 / \mathrm{jlp} .18005$. spe.

Pickthall, M. The Meaning of the Glorious Qur'an: Text and Explanatory Translation, Beirut, Dār Al-Kitāb Al-lubnānī, 1930, al-furkan: 52

Pickthall, M. W. (1999). The meaning of the glorious Qur'an: text and explanatory translation. Amana Publications.

Pipes, D. (2002). Militant Islam Reaches America. New York: W W Norton \& Co Inc.

Qarai, A. Q. (2004). The Quran: With a phrase by phrase English translation. London: Islamic College for Advanced Studies Press (ICAS).

Qutb, S. (1983) Mā'alim fì-l-tarīq,, Kuwait: Islamic Federation for Student Organization.

Sale, G. (1734). The Koran, Create Space Independent Publishing Platform.

Sharifian, F. (2007). Politics and/of Translation: Case studies between Persian and English. Journal of intercultural studies, 28(4), 413-424

Taibi, M., \& Martin, A. (2012). Court Translation and Interpreting in Times of "the War on Terror": The case of Taysir Alony. Translation \& Interpreting, 4(1), 77-98

Ünal, A. (2006). The Qur'an with Annotated Interpretation in Modern English. Tughra Books.

Venuti (1998) The Scandals of Translation: Towards an Ethics of Difference, London and New York: Routledge.

Venuti, L. (1992) Rethinking Translation: Discourse, Subjectivity, Ideology, London: Routledge.

Zādā, A. (1998). Mūgma Al-Anhur. Beirut: Dar Ihy'a Al-Tūrāt Al-Arbi.

\section{Electronic Sources}

Al-Būghdādī, A. Book 13/523 - 524, available at https://islamqa.info/ar/127009, (accessed 30 October 2018)

Al-Uțaymīn, M. Al-Utaymīn's fatwa http://www.dd-sunnah.net/forum/showthread.php

Crone, P. "Jihad: An Idea and History," Open Democracy: Free Thinking to the world, April $302007 . \quad$ Available at: https://www.opendemocracy.net/faitheurope_islam/jihad_4579.jsp (accessed 20 October 2018). 
Ibn Baz's,Book on Hadith Mawdu', No. 26; P. 381, available at: http://www.alifta.net/fatawa/fatawaDetails.aspx?languagename $=$ en $\&$ BookID $=14 \&$ View=Page\&PageNo=1\&PageID=5220, , (accessed 30 October 2018).

Ibn Manzūr, in Lisān al-Arab, retrieved from https://www.maajim.com/dictionary.

\section{Appendix 1.}

Concordance of the word 'jihād' in a tagged corpus of Quran (in Arabic)

$$
\begin{aligned}
& \text { في سبيل الله بامو ال كم و انفس كم ذلكم خير ل كم ان كنتم تعلمون }
\end{aligned}
$$

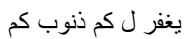

$$
\begin{aligned}
& \text { في سبيل الله لا يستوون عند الله و الله لا يهدي القوم الظالمين الذين } \\
& \text { امنواو } \\
& \text { الكفار و المنافقين و اغلظ علي هم و ماوا هم جهنم و بئس المصير } \\
& \text { يحلفون باله ما والمنافين } \\
& \text { ف انما يجاهد ل نفسه ان الله ل غني عن العالمين و الذين امنواو و بال }
\end{aligned}
$$

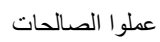

$$
\begin{aligned}
& \text { الكفار و المنافقين و اغلظ علي هم و ماوا هم جهنم و بئس المصبر }
\end{aligned}
$$

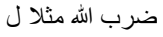

$$
\begin{aligned}
& \text { لتشرك بي ما ليس للك به علم ف لا تطع هما الي مرجع كم ف }
\end{aligned}
$$

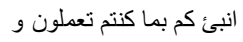

$$
\begin{aligned}
& \text { على ان تشرك بي ما ليس للك به علم ف لا تطع هما و صاحب نكان }
\end{aligned}
$$

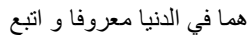

$$
\begin{aligned}
& \text { به جهادا كبير او هو الذي مرج البحرين هذا عذب فروات اتبع و هذا } \\
& \text { ملح اجاج و جعل بين } \\
& \text { في سبيل الله اولئك برجون رحمت الله و الله غفور رحيم يسالونك }
\end{aligned}
$$

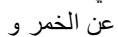

$$
\begin{aligned}
& \text { من كم و يعلم الصابرين و لقد كنتم تمنون الموت من قبل ان تلقوه }
\end{aligned}
$$

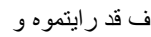

$$
\begin{aligned}
& \text { في سبيله لعلكم تفلحون ان الذين كفروا لو ان ل هم ما في الارض }
\end{aligned}
$$

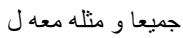

$$
\begin{aligned}
& \text { بامو الهم و انفس هم في سبيل الله و الذين اووا و نصروا اولئك } \\
& \text { بعض هم اولباء بعض النض }
\end{aligned}
$$

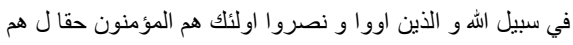

$$
\begin{aligned}
& \text { مغفرة و رزق كريم الاين } \\
& \text { مع كم فاولئك من كم و اولو الارحام بعض هم هم اولى ببعض في } \\
& \text { كتاب الله ان الله بكل } \\
& \text { من كم و لم يتخذوا من دون الهه و لا رسوله و لا المؤمنين و ليجة }
\end{aligned}
$$

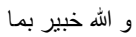

$$
\begin{aligned}
& \text { في سبيل الله باموال هم و انفس هم اعظم درجة عند الله و اولئك }
\end{aligned}
$$

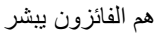

$$
\begin{aligned}
& \text { بامو الكم و انفس كم في سبيل الله ذلكم خير ل كم ان كنتم تعلمون } \\
& \text { لو كان عرضا لو النما } \\
& \text { مع رسوله استاذنك اولو الطول من هم و قالو ا ذرنا نكن مع }
\end{aligned}
$$

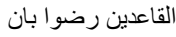

$$
\begin{aligned}
& \text { بامو الهم و انفس هم و اولئك ل هم الخيرات و اولئك هم المفلحون } \\
& \text { اعد الله ل هم }
\end{aligned}
$$

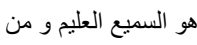


و صبروا ان ربك من بعد هال غفور رحيم يوم ثاني كل نفس تجادل عن نفس ها و توفى كل هال

في الله حق جهاده هو اجتباكم و ما جعل علي كم في الدين من في حرج ملة ابي كم ابر اهيم

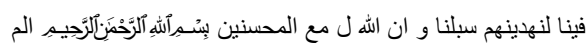

بامو ال هم و انفس هم في سبيل الله اولئك هم الصادقون قل اتعلمون الله بدين كم و هم في

كبيرا و هو الذي مرج البحرين هذا عذب فرات و هذا ملح اجاجو جعل بين هما برزخاو البر البري

في سبيلي و ابتغاء مرضاتي تسرون الي هم بالمودة و انا اعلم بما

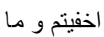

هو اجتباكم و ما جعل علي كم في الدين من حرج ملة ابي كم

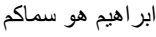

في سبيل الله بامو ال هم و انفس هم فضل الله المجاهدين بامو ال هم

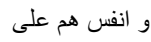

بامو ال هم و انفس هم على القاعدين درجة و كلا وعد الله الحسنى و فضل الش هر

على القاعدين اجرا عظيما درجات منها و مغفرة و رحمة و كان

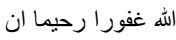

من كم و الصابرين و نبلو اخباركم ان الذين كفروا و صدوا عن

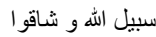

في سبيله فتربصو ا حتى ياتي الله بامرهو الله لا يهدي القوم الفاسقين لقد نصر

لنفسه ان الله لغني عن العالمين و الذين امنوا و عملوا الصالحات ل نكفرن عن هم ان للغي

بامو ال هم و انفس هم و الله عليم بالمتقين انما يستاذنك الذين لا

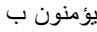

بامو ال هم و انفس هم في سبيل الله و قالوا لا تنفروا في الحر قل نار جهنم اشد حرا في سبيل الله و لا يخافون لومة لائم ذلك فضل الله يؤتيه من يشاء و الله واسع
لا جرم ان هم في الاخرة هم الخاسرون ثم ان ربك ل الذين جاهدوا

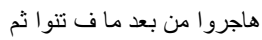

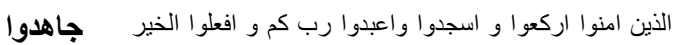

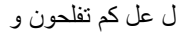

على الله كنبا او كنب بالحق ل ما جاءه اليس في جهنم مثوى جاهدوا

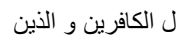

ان الله غفور رحيم انما المؤمنون الذين امنو ا باله و رسوله ثم جاهداوا

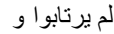

الا كفورا و لو شئنا ل بعثا في كل قرية نذيرا ف لا تطع جهادا

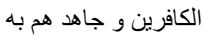

بما جاء كم من الحق يخرجون الرسول و ايا كم ان تؤمنوا باله جهادا رب كم ان كتنم خرجتم

و اسجدو ا و اعبدو ا رب كم و افعلوا الخير ل عل كم تفلحون و جهاده

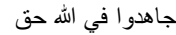

الله كان بما تعلون خبيرا لا يستوي القاعدون من المؤمنين المجاهدو ن

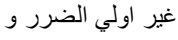

غير اولي الضرر و المجاهدون في سبيل الله باموال هم و المجاهد انفس هم فضل الله

ب اموال هم و انفس هم على القاعدين درجة و كلا وعد الله المجاهد ين

الحسنى و فضل اله اله هر

هم بسيما هم و ل نعرفن هم في ل حن القول و الله يعلم المجاهد

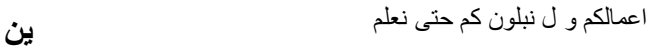

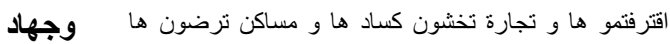

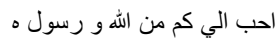

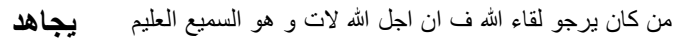

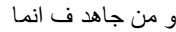

صدقوا و تعلم الكاذبين لا يستاذنك الذين يؤمنون باله و اليوم يجاهدوا

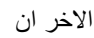

لا يهدي القوم الفاسقين فرح المخلفون بمقعد هم خلاف رسول بجاهدوا

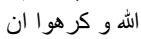

فسوف ياتي اله بقوم يحب هم و يحبونه اذلة على المؤمنين يجاهدون اعزة على الكافرين 